YANGZHOU

A PLACE IN

LITERATURE 

YANGZHOU

\section{A PLACE IN} LITERATURE

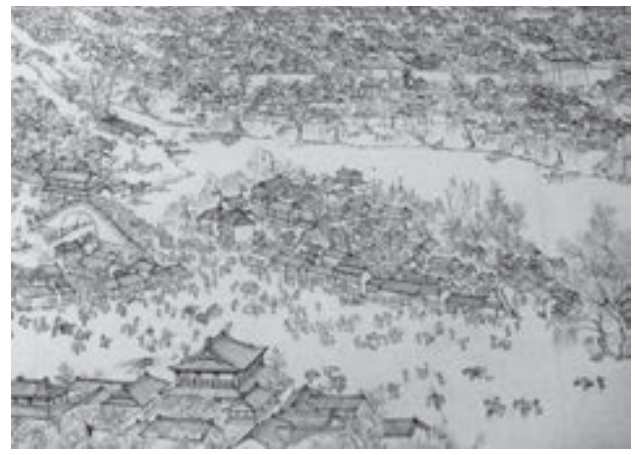

The Local in Chinese Cultural History
Edited by

Roland Altenburger,

Margaret B. Wan, and Vibeke Børdahl

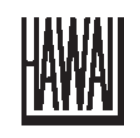

University of Hawai'i Press

Honolulu 
The publication of the present volume was supported by a Publication Subsidy Grant of the Chiang Ching-kuo Foundation for International Scholarly Exchange.

(C) 2015 University of Hawai'i Press

All rights reserved

Printed in the United States of America

$201918171615 \quad 6554321$

\section{Library of Congress Cataloging-in-Publication Data}

Yangzhou, a place in literature : the local in Chinese cultural history / edited by Roland Altenburger, Margaret B. Wan, and Vibeke Børdahl.

pages $\mathrm{cm}$

Includes bibliographical references and index.

ISBN 978-0-8248-3988-8 (hardcover : alk. paper)

1. Yangzhou (Jiangsu Sheng, China)-History. 2. Yangzhou (Jiangsu Sheng, China)In literature. 3. Chinese literature-Translations into English. I. Altenburger, Roland, editor. II. Wan, Margaret B., editor III. Børdahl, Vibeke, editor.

DS797.56.Y374Y362 2015

951'.136-dc23

2014029524

University of Hawai i i Press books are printed on acid-free paper and meet the guidelines for permanence and durability of the Council on Library Resources.

Designed by George Whipple

Printed by Sheridan Books, Inc. 
In Memory of Patrick Hanan

1927-2014 
